\title{
Killing of Gram-negative Bacteria by Lactoferrin and Lysozyme
}

Richard T. Ellison III**\$ and Theodore J. Gieh"*

${ }^{*}$ Medical and ${ }^{\ddagger}$ Research Services, Department of Veterans Affairs Medical Center, and Division of Infectious Diseases, Department of Medicine, University of Colorado School of Medicine, Denver, Colorado 80220

\begin{abstract}
Although lactoferrin has antimicrobial activity, its mechanism of action is not fully defined. Recently we have shown that the protein alters the Gram-negative outer membrane. As this membrane protects Gram-negative cells from lysozyme, we have studied whether lactoferrin's membrane effect could enhance the antibacterial activity of lysozyme. We have found that while each protein alone is bacteriostatic, together they can be bactericidal for strains of $V$. cholerae, $S$. typhimurium, and $E$. coli. The bactericidal effect is dose dependent, blocked by iron saturation of lactoferrin, and inhibited by high calcium levels, although lactoferrin does not chelate calcium. Using differing media, the effect of lactoferrin and lysozyme can be partially or completely inhibited; the degree of inhibition correlating with media osmolarity. Transmission electron microscopy shows that $E$. coli cells exposed to lactoferrin and lysozyme at 40 mOsm become enlarged and hypodense, suggesting killing through osmotic damage. Dialysis chamber studies indicate that bacterial killing requires direct contact with lactoferrin, and work with purified LPS suggests that this relates to direct LPS-binding by the protein. As lactoferrin and lysozyme are present together in high levels in mucosal secretions and neutrophil granules, it is probable that their interaction contributes to host defense. (J. Clin. Invest. 1991. 88:1080-1091.) Key words: Escherichia coli • Salmonella typhimurium • Vibrio cholerae $\bullet$ lipopolysaccharide • transferrin • iron
\end{abstract}

\section{Introduction}

The proteins lysozyme and lactoferrin are major components of the specific granules of human polymorphonuclear leukocytes and are also found in high concentration in human mucosal secretions, including those of the eye, the oropharynx, the breast, the respiratory tract, and the vagina (1-3). Several lines of evidence suggest that their localization at these sites is related to roles in the human host defense system. First, during the inflammatory response both are actively secreted by the polymorphonuclear leukocyte into the external environment as this cell releases the contents of its specific (secondary) granules

Portions of this work were presented 18 September 1989 at the 29th Interscience Conference Antimicrobial Agents and Chemotherapy, Houston, TX (Abstr. No. 174) and on 6 May 1990, at the National Meeting, American Federation for Clinical Research, Washington, DC, and were published in abstract form (1990. Clin. Res. 38:392a).

Received for publication 17 August 1990 and in revised form 16 April 1991.

J. Clin. Invest.

(c) The American Society for Clinical Investigation, Inc.

$0021-9738 / 91 / 10 / 1080 / 12 \$ 2.00$

Volume 88, October 1991, 1080-1091
(4). Second, each of the proteins has been found to have independent antimicrobial activity (5-7).

Human lysozyme is a $1,4-\beta-N$-acetylmuramidase that enzymatically degrades a glycosidic linkage of bacterial peptidoglycan (8). Proteins with comparable activity have been identified in essentially all vertebrates suggesting that this is a highly conserved enzyme. Acting alone human lysozyme lyses and kills several Gram-positive microorganisms by damaging their surface-exposed peptidoglycan. In contrast, most Gram-negative organisms are resistant to killing by the protein. In these organisms an outer membrane shields the peptidoglycan murein sacculus from the external environment $(9,10)$. As lysozyme cannot easily penetrate the outer membrane, the organisms are resistant to its effects and the protein has routinely been considered to have at most a secondary function in the host defense against these pathogens (11).

Lactoferrin was first recognized as a high-affinity iron chelator in human milk, but in the 1960 s was found to have bacteriostatic properties $(2,12)$. Because these effects on bacteria could be markedly reduced or eliminated by iron saturation of the protein, it was hypothesized that lactoferrin acts to deprive microorganisms of the essential nutrient iron (13). Whereas subsequent work has continued to confirm this theory, several studies have indicated that lactoferrin may be directly bactericidal and that it can also markedly enhance the activity of secretory IgA (sIgA) (14-17). These observations suggest that lactoferrin has additional mechanisms of action towards bacteria beyond those related to iron deprivation.

Recent work in our laboratory has confirmed such activity. We have found that lactoferrin, and the related iron chelator transferrin, can damage the outer membrane of enteric Gramnegative bacilli (18-20). To varying degrees the two proteins cause release of LPS molecules from the bacterial cell, sensitize organisms to antibiotics such as rifampin and cefotaxime, and enhance susceptibility to the detergent deoxycholate. This constellation of properties is similar to those of a number of different agents that permeabilize the Gram-negative outer membrane, including metal chelators such as EDTA and polycationic compounds such as polymyxin $B$ nonapeptide, poly-l-lysine, the defensins, and the bactericidal permeability increasing protein of neutrophils (BPI) (21-24). In that these agents can enhance the susceptibility of Gram-negative organisms to lysozyme by increasing penetration of the protein through the outer membrane, we have undertaken studies to determine if lactoferrin and transferrin could have comparable effects. Additionally, as lactoferrin and lysozyme almost always coexist in vivo, demonstration of an interaction is of both physiological and mechanistic relevance.

\section{Methods}

Lactoferrin, transferrin, and lysozyme. Human milk lactoferrin was purchased commercially (Sigma Chemical Co., St. Louis, MO, or Calbiochem-Behring Corp., La Jolla, CA), as was human serum trans- 
ferrin (Sigma Chemical Co.) and human placental lysozyme (Calbiochem-Behring Corp.). Iron-saturated lactoferrin was obtained both commercially and prepared according to the method of West and Sparling (25). For selected experiments further purification of the commercial lysozyme was performed on an FPLC system (Pharmacia Fine Chemicals, Piscataway, NJ) using a Mono S column (Pharmacia Fine Chemicals) and $0.01 \mathrm{M}, \mathrm{pH} 7.0$, imidazole buffers (buffer A was imidazole alone, and buffer $\mathrm{B}$ imidazole with $1 \mathrm{M} \mathrm{NaCl}$ ) in a series of linear gradients with the following parameters: flow rate $1 \mathrm{ml} / \mathrm{min}, 0-5 \mathrm{~min}$ 0\% buffer B, 8 min 17\% buffer B, 55 min 22\% buffer B, 60 min 100\% buffer B. Eluted fractions were tested for lysozyme lytic activity on Micrococcus luteus agar plates (26). Immunological identity was confirmed by double immunodiffusion using goat anti-human lysozyme (Kallestad, Austin, TX) and subsequent SDS-PAGE. Material from two runs was pooled, concentrated, and rechromatographed under identical conditions. This material was concentrated before use in time-kill assays.

Analytic procedures. Protein concentrations were determined either by the biuret or the bicinchoninic acid-copper sulfate techniques $(27,28)$. The levels of iron in individual samples were measured using flameless atomic absorption spectrophotometry (model 5000 spectrophotometer [Perkin-Elmer Corp., Norwalk, CT] equipped with a model 500 programmer and an AS-1 auto sampler) in the laboratory of Dr. Allen Alfrey (Department of Veterans Affairs Medical Center [DVAMC], Denver, CO). The osmolarity of solutions was determined by freezing point depression (Laboratory Wide-Range Model 3WII Osmometer; Advanced Instruments, Needham Heights, MA). Determination of concentrations of sodium, potassium, chloride, bicarbonate, calcium, and magnesium were performed in the Clinical Chemistry Laboratory of the Denver DVAMC. Analysis of carbohydrate fermentation by bacteria was performed using modified chromogenic assays in a microtiter system (MicroScan, West Sacramento, CA) (29). Measurement of LPS concentration was performed using a quantitative, kinetic, chromogenic limulus amebocyte lysate assay (Whittaker M. A. Bioproducts, Walkersville, MD) with a kinetic ELISA reader and software system (Molecular Devices, Menlo Park, CA) using purified $E$. coli O55 B5 endotoxin as a standard. Discontinuous SDS-PAGE analysis of proteins was performed in a modified Laemmeli system using $1.5-\mathrm{mm}$ slab gels with $4.5 \%$ stacking and $10 \%$ resolving sections, and subsequent analysis by silver stain (30-32). The methods of PerezPerez and Blaser were used for SDS-PAGE of bacterial LPS (33). Briefly, pelleted cells were resuspended in $200 \mu$ l solubilizing buffer and the supernatants lyophilized and resuspended in $100 \mu \mathrm{l}$ solubilizing buffer. All samples were treated with proteinase $\mathrm{K}$ for $1 \mathrm{~h}$ at $60^{\circ} \mathrm{C}$ and boiled for $10 \mathrm{~min}$. Discontinuous SDS-PAGE using the Laemmeli system was performed with $4.5 \%$ stacking and $15 \%$ resolving gels and analysis by silver stain (34).

Bacterial strains. Vibrio cholerae 3083 was obtained from Dr. Mary Boesman-Finkelstein (University of Missouri, Columbia, MO); the O111 B4 UDP galactose epimerase deficient Escherichia coli CL99-2 strain from Dr. Keith A. Joiner (National Institutes of Health, Bethesda, MD); and Salmonella typhimurium strain SL696 from Dr. Ilkka M. Helander (National Public Health Institute, Helsinki, Finland) $(16,35-38)$. E. coli 5448 is a human gastrointestinal isolate from the University of Colorado Health Sciences Center Clinical Microbiology Laboratory (19). SDS-PAGE analysis of bacterial LPS demonstrated that all four strains had a "smooth" wild-type LPS phenotype (data not shown).

Time-kill studies. Peptone media were obtained commercially (Difco, Detroit MI) and 1\% wt/vol solutions prepared. WMS, Davis and Luria broth were prepared according to published recipes $(18,39-$ 41). Bacteria were grown to stationary phase, the cells centrifuged and washed. A $5 \times 10^{5} \mathrm{CFU}$ bacterial inoculum was added to $500 \mu \mathrm{l}$ of media with or without transferrin $(2.0 \mathrm{mg} / \mathrm{ml})$, lactoferrin $(2.0 \mathrm{mg} / \mathrm{ml})$, lysozyme $(0.5 \mathrm{mg} / \mathrm{ml})$, or EDTA $\left(8 \times 10^{-5} \mathrm{M}\right)$. The mixtures were incubated at $37^{\circ} \mathrm{C}$, aliquots removed, serially diluted, and plated overnight at $37^{\circ} \mathrm{C}$ on soybean casein digest agar (Sigma Chemical Co.). For studies with $V$. cholerae 3083 the strain was grown to stationary phase in proteose peptone 3 with $0.3 \mathrm{mM} \mathrm{CaCl}$ and then tested in proteose peptone 3. For all other strains, bacterial cells were grown and tested in the same media. For osmolarity studies, $1 \%$ bacto-peptone was supplemented with myo-inositol (Sigma Chemical Co.). For selected experiments $E$. coli 5448 cells were grown for $24 \mathrm{~h}$ in $1 \%$ bacto-peptone with $0.05 \mathrm{mg} / \mathrm{ml}$ lysozyme, washed, and then incubated with lactoferrin and lysozyme as above. Dialysis cell studies were performed with $1 \%$ bactopeptone in $1 \mathrm{ml}$ equilibrium dialysis chambers with 6,000 Dexclusion regenerated-cellulose membranes (Bel-Art, Pequannock, NJ).

Transmission electron microscopy (TEM). $5 \times 10^{8}$ CFU inocula of $E$. coli 5448 were added to $500 \mu \mathrm{l}$ of $1 \%$ bacto-peptone with or without lactoferrin $(2.0 \mathrm{mg} / \mathrm{ml})$ or repurified lysozyme $(0.005 \mathrm{mg} / \mathrm{ml})$. The mixtures were incubated at $37^{\circ} \mathrm{C}$ for $24 \mathrm{~h}$ and the bacterial cells pelleted. The pellets were resuspended in $2 \%$ glutaraldehyde in $0.1 \mathrm{M}$

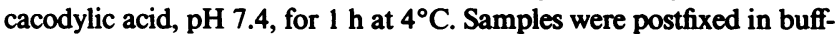
ered $1 \%$ osmium tetroxide, dehydrated through a graded series of ethanols, and embedded in poly/bed 812-araldite (Mollenhauer medium; Polysciences, Inc., Warrington, PA). For electron microscopy, 70-nm thin sections were obtained with diamond knives and stained routinely with aqueous solutions of uranyl acetate and lead citrate. Sections were examined with a Philips CM-12 transmission electron microscope at $60 \mathrm{kV}$.

Equilibrium dialysis studies. Binding of calcium was studied by adding $750 \mu \mathrm{l}$ of a solution of ${ }^{45} \mathrm{CaCl}_{2}$ in $\mathrm{pH} 7.4 \mathrm{HBSS}$ lacking calcium and magnesium (HBSS-CM) (Whittaker M. A. Bioproducts) to one side of acrylic equilibrium dialysis cell chambers with $6,000 \mathrm{D}$ exclusion regenerated-cellulose membranes. To the opposite side of the dialysis chambers were added solutions of either $2 \mathrm{mg} / \mathrm{ml}$ of BSA (Sigma Chemical Co.), transferrin, lactoferrin, apo- or iron-saturated lactoferrin, or $260 \mu$ l of $20 \%$ Chelex 100 (Bio-Rad Laboratories, Inc., Richmond, CA) in HBSS-CM. The cells were allowed to equilibrate at room temperature and serial aliquots sampled over $96 \mathrm{~h}$.

LPS binding studies. To study the ability of the iron-binding proteins to bind LPS; lactoferrin, transferrin, BSA, poly-l-lysine (Sigma Chemical Co.), and soybean trypsin inhibitor (Sigma Chemical Co.) were coupled to cyanogen bromide-activated Sepharose 4B beads (Pharmacia Fine Chemicals) at a concentration of $1 \times 10^{-7} \mathrm{~mol} / \mathrm{ml}$ gel (molecular weight range of poly-l-lysine is $1,000-4,000$, and was estimated at 2,000). After protein coupling the beads were blocked in $\mathrm{pH}$ 8.0 Tris buffer, and stored in pH 7.2, 0.03 M barbital-acetate, $0.116 \mathrm{M}$ $\mathrm{NaCl}$ buffer (BABS) with $0.02 \%$ thimerosol. To control for nonspecific binding, Sepharose beads were also prepared that were not reacted with protein, but instead simply blocked with Tris.

Tritium-labeled LPS was prepared by growing $E$. coli CL99-2 in modified WMS broth supplemented with D- $\left[6-{ }^{3} \mathrm{H}\right]$ galactose (Amersham Corp., Arlington Heights, IL), and extracting LPS either by washing the cells in pH 8.0 barbital-acetate buffer or by the phenol-water method of Westphal $(18,42)$. When this strain is grown in the presence of $\left[{ }^{3} \mathrm{H}\right]$-galactose, the radiolabel is almost exclusively incorporated into the LPS $O$-polysaccharide (35). For experiments requiring high LPS concentrations the $\left[{ }^{3} \mathrm{H}\right]$-LPS was supplemented with similarly prepared unlabeled LPS.

Binding of the LPS was determined by incubating $0.1 \mathrm{ml}$ of the protein-Sepharose or Tris-Sepharose beads with varying concentrations of $\left[{ }^{3} \mathrm{H}\right]$-LPS in pH 7.2 BABS for 5 min with gentle shaking. The beads were then pelleted by centrifugation, washed twice with BABS, and the beads and pooled BABS wash material counted by liquid scintillation.

\section{Results}

Interaction of lactoferrin and lysozyme. Initial studies were performed addressing the effects of lactoferrin and lysozyme against $V$. cholerae 3083 based on a preliminary observation of Boesman-Finkelstein and Finkelstein that this strain could be killed by human milk lactoferrin and lysozyme (16). We found that over $24 \mathrm{~h}$ this strain consistently demonstrated over a 1,000 -fold increase in $\mathrm{CFU} / \mathrm{ml}$ when grown either in proteose peptone 3 broth alone or with $0.5 \mathrm{mg} / \mathrm{ml}$ human lysozyme 



Figure 1. (A) Effects of lysozyme (LYS) $(0.5 \mathrm{mg} / \mathrm{ml})$ and human apo- and iron-saturated lactoferrin (LF) $(2.0 \mathrm{mg} / \mathrm{ml})$ on the growth of $V$. cholerae 3083 in $1 \%$ proteose peptone 3 (mean \pm SEM, seven experiments; 6-, 8-, and 20-h findings represent three, three, and two observations respectively). (B) Effects of lysozyme (LYS) $(0.5 \mathrm{mg} / \mathrm{ml})$, transferrin (TF) $(2.0 \mathrm{mg} / \mathrm{ml})$, and $8 \times 10^{-5} \mathrm{M}$ EDTA on the growth of $V$. cholerae 3083 in $1 \%$ proteose peptone 3 (mean \pm SEM, seven experiments; 6-, 8-, and 20-h findings represent three, three, and two observations, respectively).

(Fig. $1 \mathrm{~A})$. In contrast, $2 \mathrm{mg} / \mathrm{ml}\left(\approx 2 \times 10^{-5} \mathrm{M}\right)$ human lactoferrin was bacteriostatic alone, and the combination of lactoferrin and lysozyme was consistently bactericidal. Iron saturation of lactoferrin inhibited both the bacteriostatic and synergistic bactericidal effect of lactoferrin. ${ }^{1}$ Parallel studies performed with $2 \mathrm{mg} / \mathrm{ml}\left(\approx 2 \times 10^{-5} \mathrm{M}\right)$ human transferrin and $8 \times 10^{-5} \mathrm{M}$ EDTA indicated that both of these chelators could also enhance the activity of lysozyme, but neither to the degree of lactoferrin (Fig. $1 \mathrm{~B}$ ).

Experiments were then performed to determine if lactoferrin and lysozyme could have similar effects on other Gramnegative organisms. Studies with $1 S$. typhimurium and $2 E$. coli strains again found that lactoferrin markedly enhanced the activity of lysozyme (Fig. 2). The strains differed in their susceptibility to the combination of lactoferrin and lysozyme as well as in their susceptibility to lysozyme combined with transferrin or EDTA. Such variability had been noted in prior studies of

1. These studies were performed with commercially obtained iron-saturated lactoferrin. Comparable results were subsequently obtained with iron-saturated lactoferrin prepared by the method of West in studies with $E$. coli 5448 . the effects of lactoferrin, transferrin, and EDTA on LPS release and antibiotic susceptibility of these strains $(18,20)$.

As $E$. coli 5448 appeared to be the most susceptible strain to the effects of lactoferrin and lysozyme, this isolate was used to define how varying either the concentration of the two proteins or the bacterial inoculum size would affect the interaction. As expected from prior observations on the effects of lactoferrin on LPS release (18), the synergistic activity of the two proteins was found to be dose dependent for lactoferrin (Fig. $3 \mathrm{~A}$ ). Comparable results were found for lysozyme (Fig. $3 \mathrm{~B}$ ). In studies with differing bacterial inocula the activity of lactoferrin and lysozyme was comparable against $5 \times 10^{5}$ and $5 \times 10^{6} \mathrm{CFU} /$ $\mathrm{ml}$, but diminished when the bacterial inoculum was increased to $5 \times 10^{7} \mathrm{CFU} / \mathrm{ml}$ (Fig. 4). To confirm that an impurity in the commercial lysozyme was not contributing to the observed interactions with lactoferrin, transferrin, and EDTA; experiments were repeated with lysozyme that was repurified by ionexchange chromatography. The purified preparation again showed a synergistic interaction with lactoferrin (data not shown).

Influence of media composition. Studies were then performed to assess the effect of media composition on the lacto- 

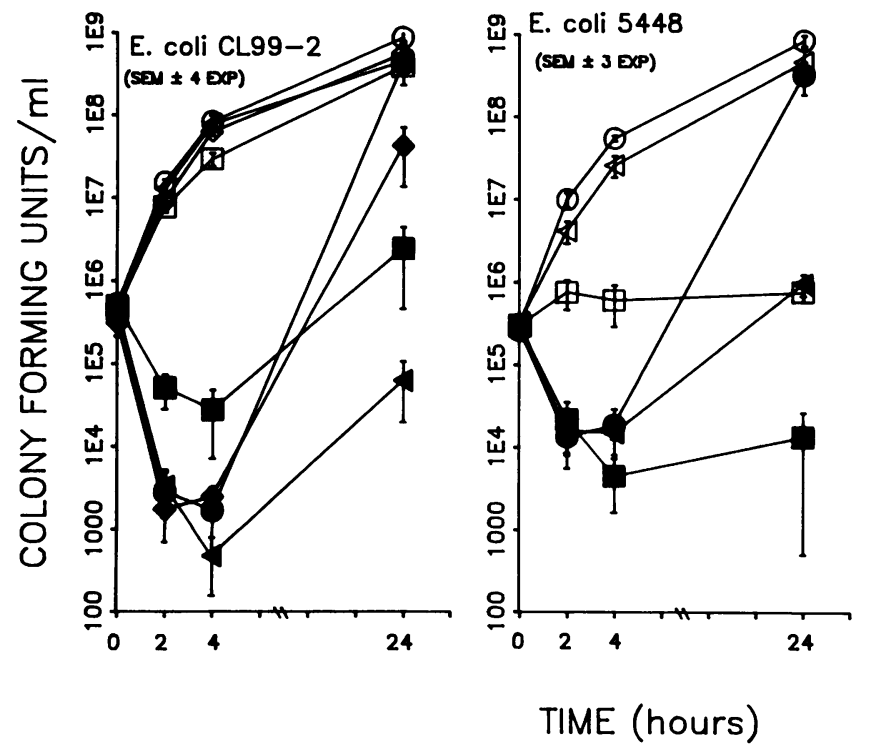

ferrin-lysozyme interaction. When other media were substituted for proteose peptone 3 in parallel experiments, the activity of lactoferrin and lysozyme towards $E$. coli 5448 changed significantly (Fig. 5). Although the effects of lactoferrin and lysozyme were similar in proteose peptone 3 and proteose peptone, the activity was enhanced in bacto-peptone. In contrast, there was no bactericidal effect noted when the strain was tested in either proteose peptone 2 or in the more defined WMS, Luria and Davis media (Table I). To determine what factors in media composition contributed to the variation in the effects of lactoferrin and lysozyme, the electrolyte composition and osmolarity of each of the media was defined. We noted no apparent relationship between the lactoferrin-lysozyme activity and concentrations of calcium, magnesium, iron, sodium, potassium, or chloride. However, there appeared

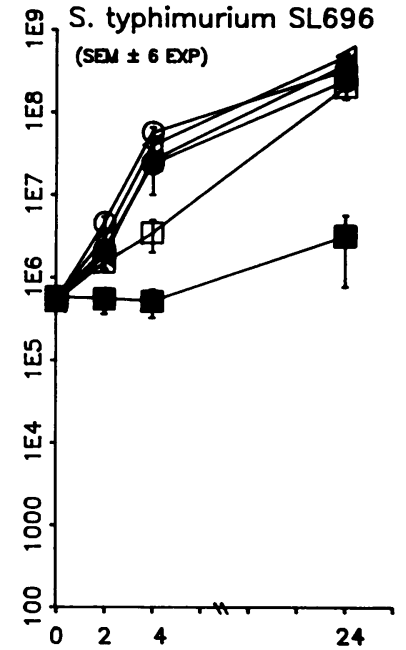

Figure 2. Effects of lysozyme, lactoferrin $(2.0 \mathrm{mg} / \mathrm{ml})$, transferrin $(2.0$ $\mathrm{mg} / \mathrm{ml}$ ), and $8 \times 10^{-5} \mathrm{M}$ EDTA on the growth of $E$. coli and $S$. typhimurium strains. Lysozyme was tested at $0.05 \mathrm{mg} / \mathrm{ml}$ for studies with E. coli strains and $0.5 \mathrm{mg} / \mathrm{ml}$ for $S$. typhimurium. (Open circles) Proteose peptone 3; (open squares) lactoferrin; (open triangles) transferrin (open diamonds) EDTA; (solid circles) lysozyme; (solid squares) lactoferrin + lysozyme; (solid triangles) transferrin + lysozyme; (solid diamonds) EDTA + lysozyme. to be a consistent inverse correlation between the degree of killing and media osmolarity. Lactoferrin-lysozyme activity was absent in media above $60 \mathrm{mOsm}$.

To test the hypothesis that media osmolarity influenced lactoferrin-lysozyme killing, parallel time-kill studies were then performed in $40 \mathrm{mOsm}$ bacto-peptone media that was supplemented with graded concentrations of a metabolically inactive material. Preliminary studies found that $E$. coli 5448 did not ferment inositol, and this sugar was used as an osmotic supplement. It was found that the addition of increasing concentrations of myo-inositol to the media did not alter the bacterial growth curve but did affect the bactericidal effects of lactoferrin and lysozyme (Fig. 6). Bacterial killing progressively decreased as the media osmolarity was increased, and was completely absent when the osmolarity was increased to 100 mOsm.

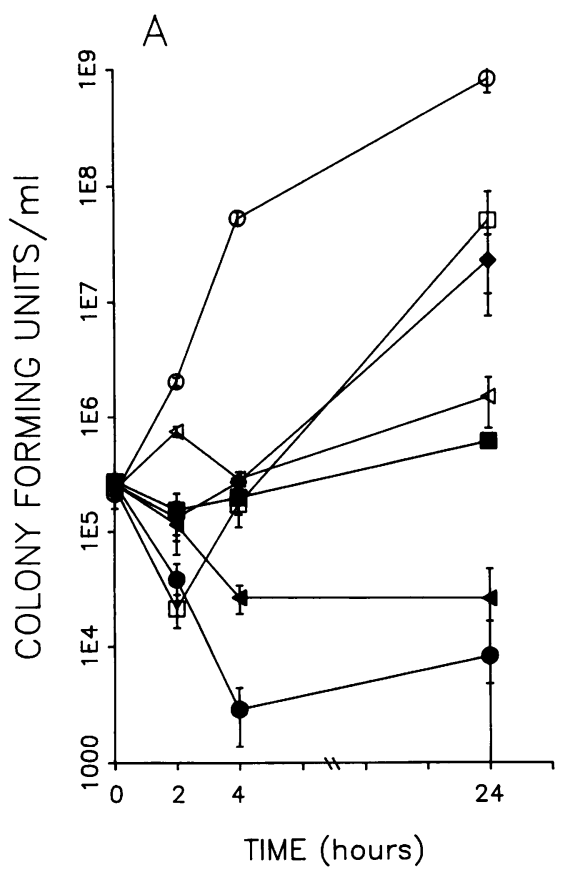



Figure 3. (A) Effect of varying lactoferrin concentration on its interaction with lysozyme against $E$. coli 5448 (mean \pm SEM, three experiments). (Open circles) Proteose peptone 3; (open triangles) $2 \mathrm{mg} / \mathrm{ml}$ lactoferrin; (open squares) $0.025 \mathrm{mg} / \mathrm{ml}$ lysozyme; (solid circles) $4 \mathrm{mg} / \mathrm{ml}$ lactoferrin + lysozyme; (solid triangles) $2 \mathrm{mg} / \mathrm{ml}$ lactoferrin + lysozyme; (solid squares) $1 \mathrm{mg} / \mathrm{ml}$ lactoferrin + lysozyme; (solid diamonds) $0.5 \mathrm{mg} / \mathrm{ml} \mathrm{lacto-}$ ferrin + lysozyme. $(B)$ Effect of varying lysozyme concentration on its interaction with lactoferrin against $E$. coli 5448 (mean \pm SEM, four experiments). (Open circles) Proteose peptone 3; (open triangles) $2 \mathrm{mg} / \mathrm{ml}$ lactoferrin; (open squares) $0.025 \mathrm{mg} / \mathrm{ml}$ lysozyme; (solid circles) lactoferrin $+0.05 \mathrm{mg} / \mathrm{ml}$ lysozyme; (solid triangles) lactoferrin +0.025 $\mathrm{mg} / \mathrm{ml}$ lysozyme; (solid squares) lactoferrin $+0.0125 \mathrm{mg} / \mathrm{ml}$ lysozyme; (solid diamonds) lactoferrin $+0.0063 \mathrm{mg} / \mathrm{ml}$ lysozyme. 

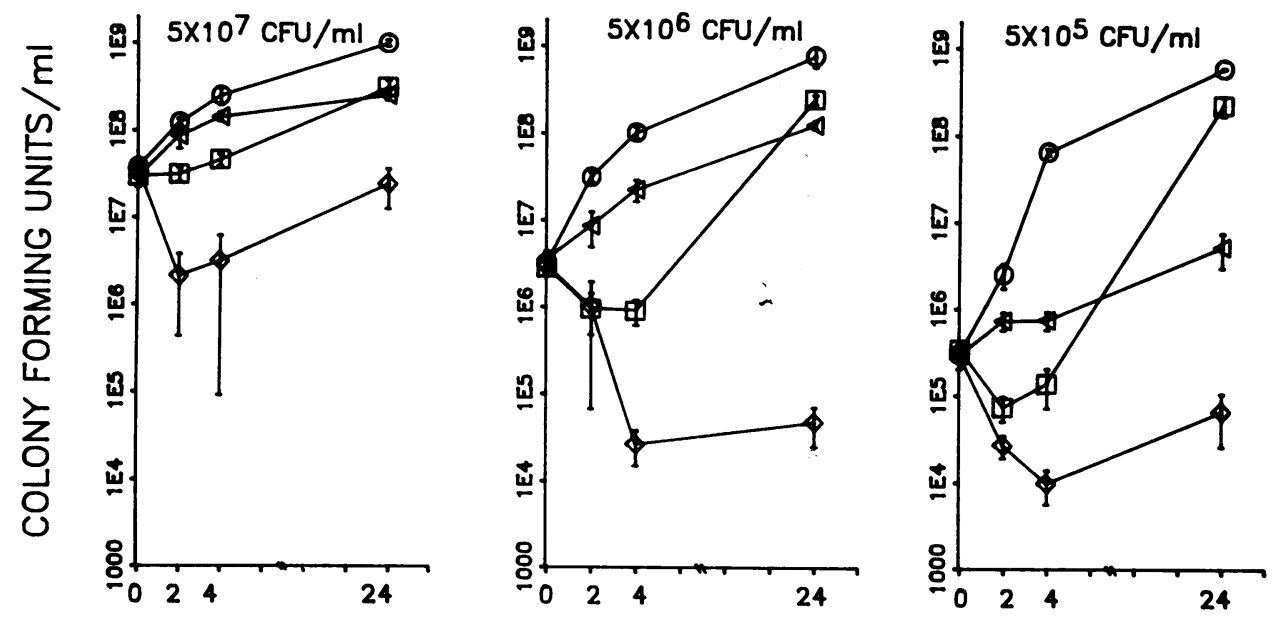

Figure 4. Effect of bacterial inoculum size on the activity of lactoferrin and lysozyme against $E$. coli 5448 (mean \pm SEM, three experiments). (Open circles) Proteose peptone 3; (open triangles) $2 \mathrm{mg} / \mathrm{ml}$ lactoferrin; (open squares) $0.05 \mathrm{mg} / \mathrm{ml}$ lysozyme; (open diamonds) lactoferrin TIME (hours)

As consistent early killing and subsequent regrowth of $E$. coli 5448 cells was observed with exposure to lysozyme alone, to determine if this represented the emergence of resistant cells,
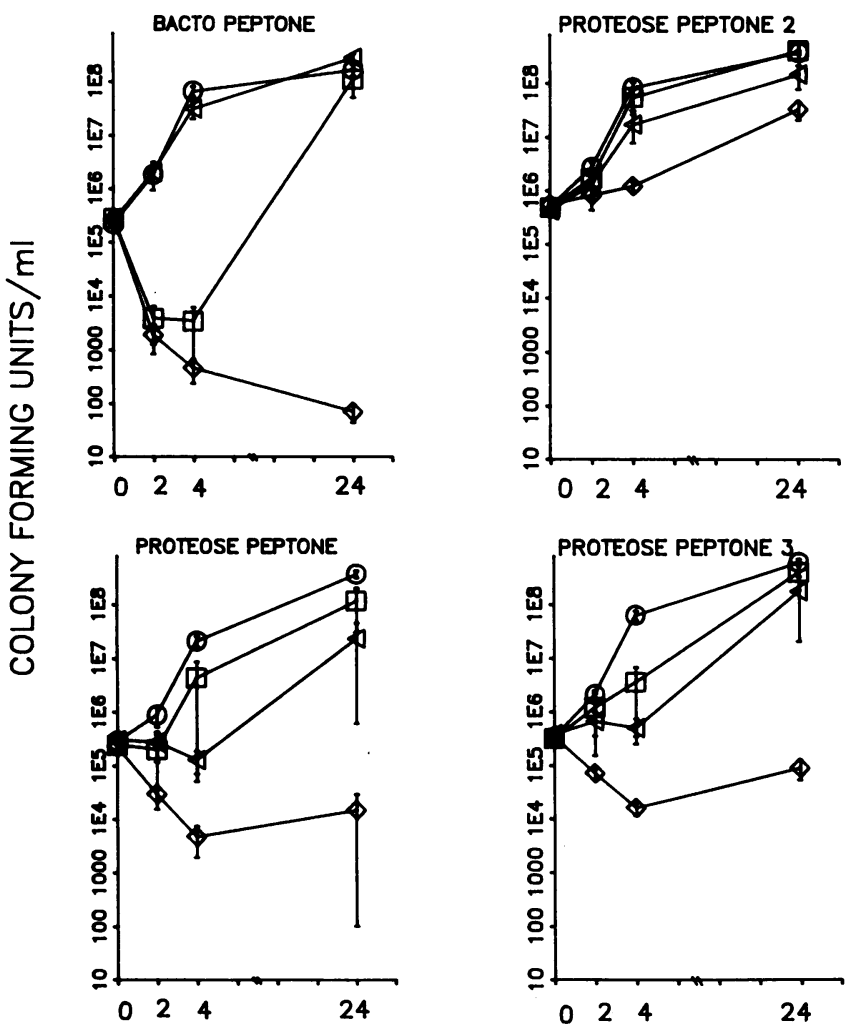

further time-kill studies were performed using cells that had been grown for $24 \mathrm{~h}$ in $1 \%$ bacto-peptone media with 0.05 $\mathrm{mg} / \mathrm{ml}$ lysozyme. It was found that these $E$. coli cells grown in the presence of lysozyme remained susceptible to the combined effects of lactoferrin and lysozyme, although in matched studies the concentration of lysozyme needed to be increased fourfold $(0.0125-0.05 \mathrm{mg} / \mathrm{ml})$ to achieve a degree of killing comparable with that of cells not previously exposed to lysozyme.

TEM studies. One model to explain the effect of media osmolarity on bacterial killing by lactoferrin and lysozyme would be that the bactericidal effect is primarily related to degradation of the peptidoglycan matrix. Without the protection of this rigid framework, under low osmotic conditions the bacterial cells would absorb fluid allowing them to balloon and explode. Such a phenomenon would not occur at high osmolarity. To evaluate this possibility, bacterial cells were examined by TEM after $24 \mathrm{~h}$ of growth in $\mathbf{4 0} \mathrm{mOsm}$ bacto-peptone with or without lactoferrin or lysozyme. It was found that the majority of bacterial cells were cylindrical when grown in media alone (Fig. $7 A$ ) or in the presence of either lactoferrin (Fig. $7 \mathrm{~B}$ ) or lysozyme (Fig. $7 \mathrm{C}$ ) individually. In contrast, in keeping with the hypothesis of damage to the peptidoglycan matrix, when cells were exposed to lactoferrin and lysozyme together (Fig. $7 \mathrm{D}$ ) there was a large amount of cell debris noted and a number of the remaining cells appeared to be quite enlarged, hypodense, and rounded.

Influence of calcium and magnesium concentration. Further work was then initiated to more precisely define how lactoferrin damages the outer membrane and alters bacterial susceptibility to lysozyme. Based on prior work indicating that the calcium and magnesium concentration could significantly influence the ability of lactoferrin and transferrin to either induce LPS release or change bacterial susceptibility to deoxycholate $(18,20)$, the effects of these cations on lactoferrin-lysozyme synergy towards $E$. coli 5448 were evaluated using concentrations similar to those studied previously. Although the addition of either $1.3 \mathrm{mM} \mathrm{CaCl}_{2}$ or $0.8 \mathrm{mM} \mathrm{MgCl}_{2}$ to bacto-peptone had only minimal effect on media osmolarity (measured osmolarity remaining $\approx 40 \mathrm{mOsm}$ ), the presence of either cation inhib- 


\begin{tabular}{|c|c|c|c|c|c|c|c|c|c|}
\hline $\begin{array}{l}\text { Media } \\
\text { studied }\end{array}$ & $\begin{array}{l}\text { Lactoferrin } \\
\text {-lysozyme } 24 \text { h } \\
\text { Log }_{10} \text { change }\end{array}$ & $\mathbf{M g}^{+2}$ & $\mathrm{Ca}^{+2}$ & $\mathrm{Fe}$ & $\mathrm{Na}^{+}$ & $\mathbf{K}^{+}$ & $\mathrm{Cl}^{-}$ & $\mathrm{CO}_{2}$ & Osmolarity \\
\hline & & $m M$ & $m M$ & $p p b$ & $m M$ & $m M$ & $m M$ & $m M$ & mOsmol \\
\hline Bacto-peptone & -3.7 & 0.1 & 0.1 & 35 & 10 & 0.7 & 12 & 3 & 41 \\
\hline Proteose peptone & -2.8 & 0.2 & 0.2 & 114 & 18 & 2.8 & 15 & 3 & 54 \\
\hline Proteose peptone 3 & -0.7 & 0.2 & 0.2 & 187 & 18 & 3.4 & 12 & 3 & 57 \\
\hline Proteose peptone 2 & 1.7 & 0.1 & 0.1 & 60 & 23 & 3.3 & 16 & 3 & 79 \\
\hline WMS II & 2 & $<0.01$ & 0.01 & 20 & 37 & 25 & 170 & 3 & 405 \\
\hline WMS III & 2 & $<0.01$ & 0.01 & 20 & 36 & 24 & 173 & 3 & 444 \\
\hline Supplemented Davis & 2 & $<0.01$ & 0.02 & - & 14 & 189 & 15 & 3 & 321 \\
\hline Luria broth & 3 & $<0.01$ & 0.002 & 550 & 22 & 8 & 15 & 3 & 110 \\
\hline
\end{tabular}

Time-kill studies were performed in triplicate in peptone media and singly in others.

ited the bactericidal effect of lactoferrin and lysozyme (Fig. 8 $A$ ). These studies were extended by evaluating the addition of 8 $\times 10^{-5} \mathrm{M}$ or $1.6 \times 10^{-4} \mathrm{M} \mathrm{CaCl}_{2}$ to the bacto-peptone media. With these lower calcium concentrations, there was partial and dose-dependent inhibition of the lactoferrin-lysozyme bactericidal interaction (Fig. 8 B).

Calcium chelation studies. A mechanism by which calcium could interfere with the lactoferrin-lysozyme bactericidal effect would be through an inhibition of the ability of lactoferrin to chelate membrane stabilizing calcium. As we were unaware of published data on the ability of lactoferrin (or transferrin) to

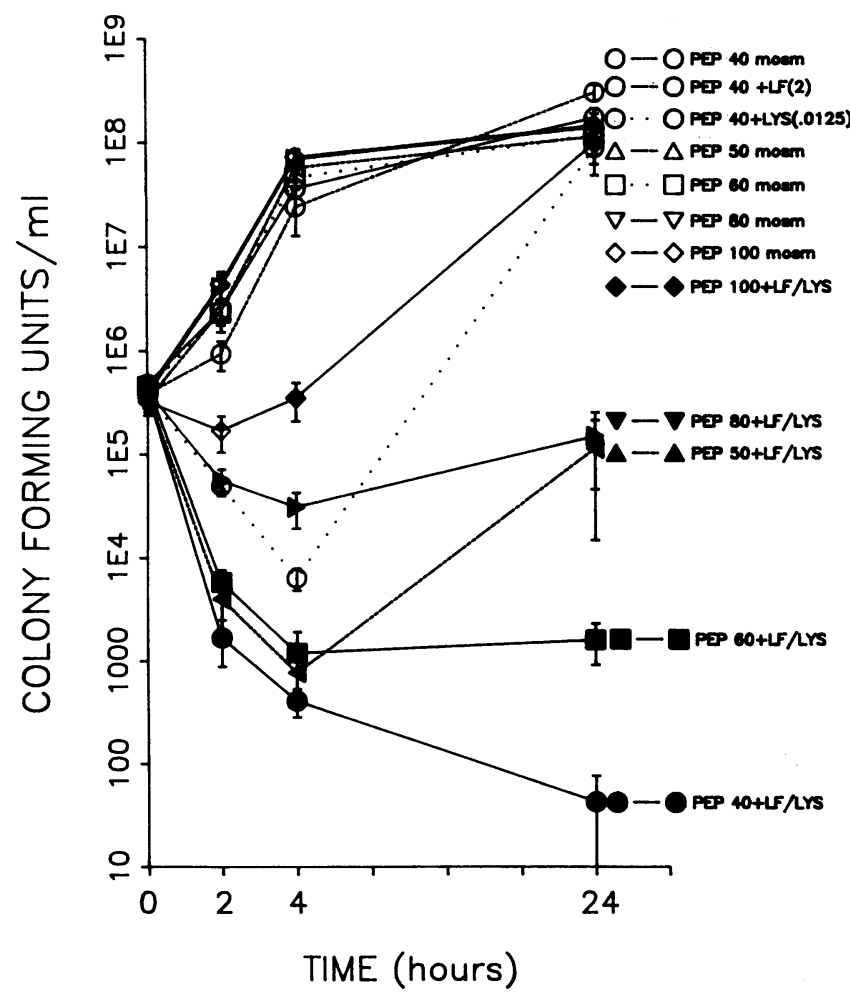

Figure 6. Evaluation of lactoferrin-lysozyme bactericidal activity towards $E$. coli 5448 in bacto-peptone media supplemented with increasing osmotic concentrations of myo-inositol (mean $\pm \mathrm{SEM}$, three experiments). chelate calcium, equilibrium dialysis studies were performed to directly define ${ }^{45} \mathrm{Ca}^{++}$binding by the proteins. HBSS-CM was chosen as the buffer for these studies as prior work had shown that in this solution the outer membrane effects of lactoferrin and transferrin were both demonstrable and calcium-dependent (20). Whereas the synthetic chelator Chelex caused the expected migration of the isotope across the dialysis chamber, neither lactoferrin or transferrin had any demonstrable effect on distribution of ${ }^{45} \mathrm{Ca}^{++}$within the dialysis chamber, the results with lactoferrin were identical with apo- and iron-saturated preparations (Table II). Thus, these studies indicate that the two proteins do not have any significant ability to chelate calcium under conditions where they have consistent outer membrane effects.

Dialysis chamber studies. To extend the studies on the mechanism by which lactoferrin enhances bacterial susceptibility to lysozyme, dialysis chamber studies with a 6,000-D exclusion membrane were then performed to define whether direct cell contact was required for lactoferrin's effects (Fig. 9). As expected, lysozyme was not active unless it was in direct bacterial cell contact. The ion exchange resin, Chelex, was found to be more active when in direct cell contact, but also enhanced lysozyme's effects when added to the opposite side of the dialysis chamber (Fig. 9 B). In contrast, lactoferrin only enhanced the effects of lysozyme when it was in direct contact with bacterial cells whether tested at concentrations of 1 or $2 \mathrm{mg} / \mathrm{ml}$ (Fig. $9 \mathrm{~A}$ ). These observations are more consistent with lactoferrin augmenting lysozyme's effects through a direct interaction with the bacterial outer membrane than with the protein acting through its chelating properties.

LPS binding studies. Polycationic agents that alter outer membrane permeability appear to directly interact with LPS molecules $(10,24,43)$. Several previous studies have indicated that lactoferrin will bind to bacterial cells, although the mechanism of binding may be related to the presence of specific bacterial lactoferrin receptors (44-46). To more carefully elucidate whether lactoferrin might be altering the outer membrane in a manner similar to polycationic agents, we studied whether lactoferrin could directly bind LPS. For these studies equimolar concentrations of human lactoferrin, human transferrin, BSA, poly-l-lysine, and soybean trypsin inhibitor (previously shown not to bind LPS [47]) were linked to Tris-blocked Sepharose beads. These protein beads were then incubated with varying 

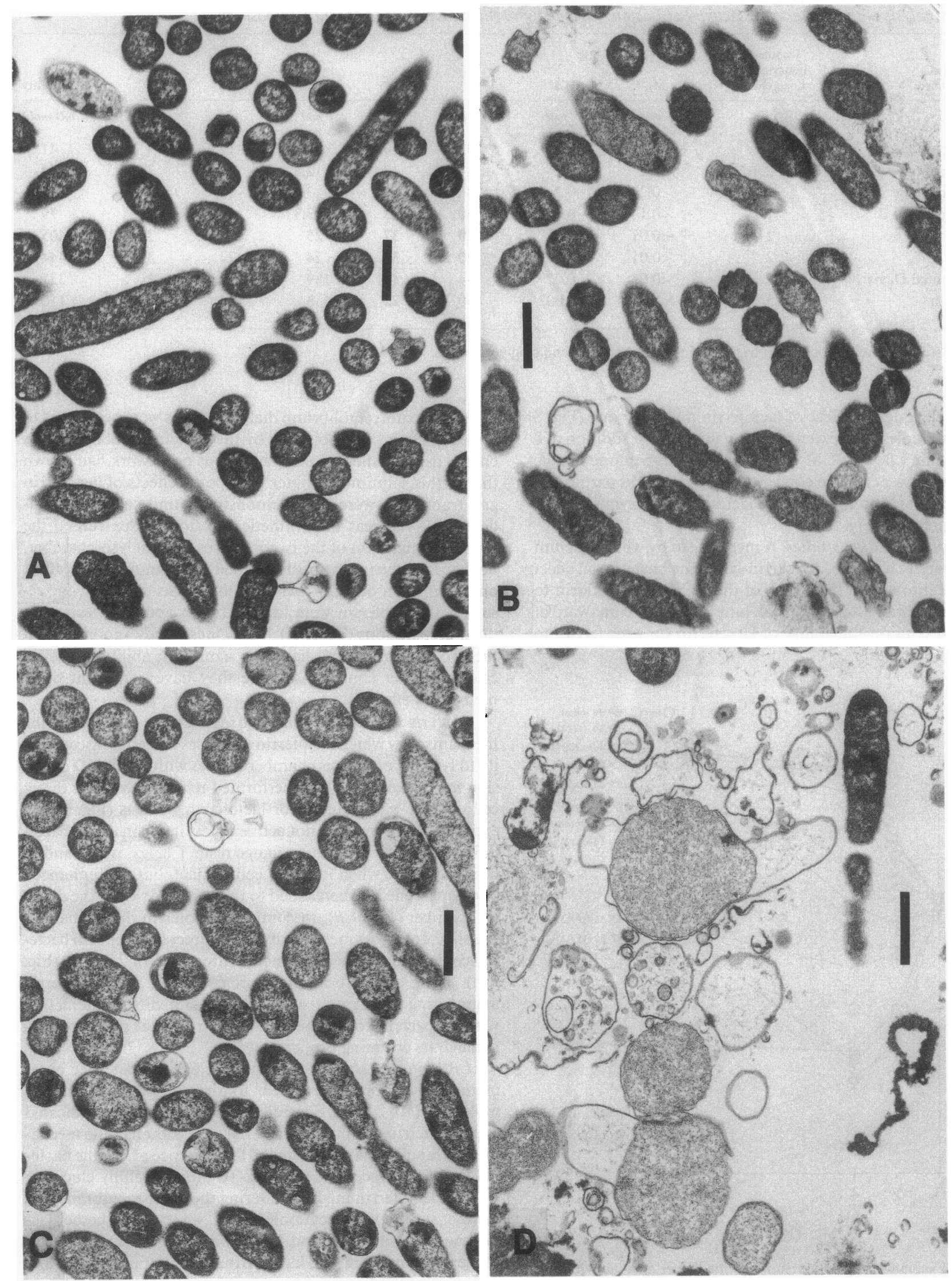

Figure 7. Transmission electron microscopy of $E$. coli 5448 cells incubated for $24 \mathrm{~h}$ in $(A)$ bacto-peptone, $(B)$ bacto-peptone with $2 \mathrm{mg} / \mathrm{ml}$ lactoferrin, $(C)$ bacto-peptone with $0.005 \mathrm{mg} / \mathrm{ml}$ lysozyme, $(D)$ bacto-peptone with lactoferrin and lysozyme (markers indicates $1 \mu \mathrm{m}$ ). 

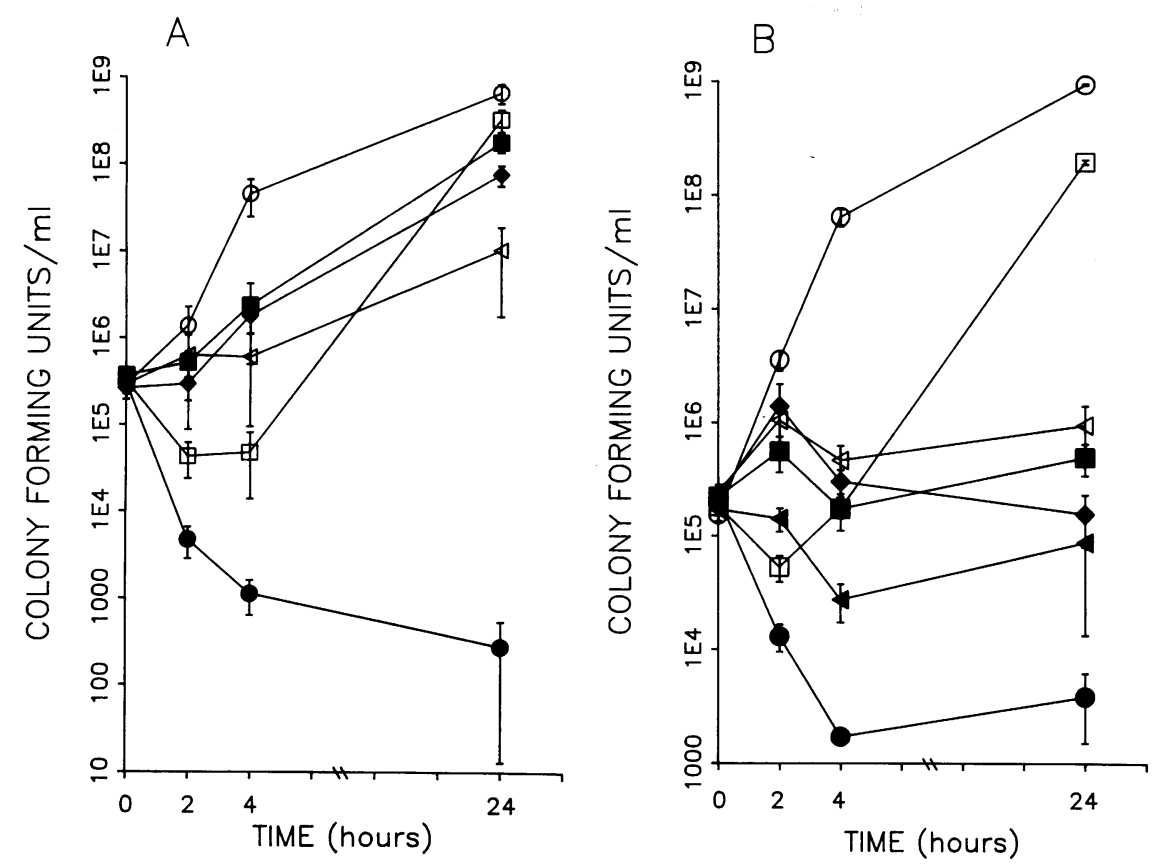

Figure 8. Effect of calcium and magnesium on lactoferrin-lysozyme bactericidal activity towards $E$. coli 5448 in bacto-peptone media (mean \pm SEM, three experiments). ( $A$ ) (Open circles) media alone; (open triangles) $2 \mathrm{mg} / \mathrm{ml}$ lactoferrin; (open squares) $0.05 \mathrm{mg} / \mathrm{ml}$ lysozyme; (solid circles) lactoferrin + lysozyme in media alone; (solid squares) lactoferrin + lysozyme in media supplemented with $1.3 \times 10^{-3}$ $\mathrm{M} \mathrm{CaCl}_{2}$; (solid diamonds) lactoferrin + lysozyme in media supplemented with $8 \times 10^{-4} \mathrm{M}$ $\mathrm{MgCl}_{2}$. (B) (Open circles) media alone; (open triangles) $2 \mathrm{mg} / \mathrm{ml}$ lactoferrin; (open squares) $0.05 \mathrm{mg} / \mathrm{ml}$ lysozyme; (solid circles) lactoferrin + lysozyme in media alone; (solid triangles) lactoferrin + lysozyme in media supplemented with $8 \times 10^{-5} \mathrm{M} \mathrm{CaCl}_{2}$; (solid squares) lactoferrin + lysozyme in media supplemented with $1.6 \times 10^{-4} \mathrm{M} \mathrm{CaCl}_{2}$.

concentrations of [ $\left.{ }^{3} \mathrm{H}\right]$-LPS prepared from $E$. coli strain CL992 (Fig. 10). The binding curves obtained indicate that lactoferrin and poly-l-lysine have a similar ability to bind LPS, and each has a distinctly greater ability to bind LPS than does the other proteins or the Tris-blocked control beads. An exact calculation of the number of LPS binding sites and the $K_{d}$ for the interactions with lactoferrin and poly-l-lysine is limited both because of the inability to define the molar concentration of LPS (due to size variability) and because of the capacity for free LPS molecules to aggregate in solution (48).

\section{Discussion}

The present studies demonstrate that lactoferrin and lysozyme synergistically kill Gram-negative bacteria. This activity is demonstrable against multiple different "smooth" bacteria, is dose dependent and influenced by bacterial inoculum size and basal growth media. The relative activity of lactoferrin and lysozyme appears to correlate with media osmolarity, and can be inhibited by increasing the osmolarity of a permissive media with a metabolically inert material. Morphological analysis of bacterial cells by TEM indicates that the bactericidal effect is associated with the formation of ballooned spheroplasts. These observations appear consistent with lactoferrin acting to increase the penetration of lysozyme into the Gram-negative organism where the enzyme can then disrupt the glycosidic linkages of the rigid murein sacculus. That lactoferrin can enhance lysozyme activity in this fashion is consistent with other observations on the outer membrane effects of lactoferrin. Previous studies have found that the protein causes LPS release and enhances bacterial susceptibility to antibiotics such as rifampin and cefotaxime (18-20).

Enteric Gram-negative bacteria are protected from the external environment by their complex outer membrane structure $(9,10)$. The membrane has an asymmetric lipid bilayer with negatively charged LPS molecules primarily localized on the outer leaflet and stabilized by the presence of divalent cations. The polysaccharide sidechain of the LPS molecule provides a hydrophilic surface to the bacterial cell, and the saturated fatty acid chains make this membrane relatively rigid as compared with other phospholipid structures (49). The dual hydrophilic/hydrophobic nature of the outer membrane

Table II. Chelation of ${ }^{45}$ Calcium by Proteins and Chelex 100 Determined by Equilibrium Dialysis

\begin{tabular}{|c|c|c|c|c|c|}
\hline \multirow[b]{2}{*}{ Chelator } & \multicolumn{5}{|c|}{ Percent migration of ${ }^{45} \mathrm{Ca}$ across dialysis membrane after differing incubation times } \\
\hline & $\mathbf{O h}$ & $2 \mathrm{~h}$ & $18 \mathrm{~h}$ & $24 \mathrm{~h}$ & $96 \mathrm{~h}$ \\
\hline BSA $(1 \mathrm{mg} / \mathrm{ml})$ & 0.03 & $24.9 \pm 2.3$ & $51.7 \pm 0.3$ & $52.3 \pm 0.6$ & $47.0 \pm 4.8$ \\
\hline Human transferrin $(1 \mathrm{mg} / \mathrm{ml})$ & 0.03 & $27.9 \pm 3.4$ & $48.4 \pm 0.4$ & $50.5 \pm 0.6$ & $51.3 \pm 0.5$ \\
\hline Human lactoferrin $(1 \mathrm{mg} / \mathrm{ml})$ & 0.03 & $27.3 \pm 3.2$ & $48.9 \pm 0.1$ & $49.6 \pm 0.3$ & $45.9 \pm 4.6$ \\
\hline \multicolumn{6}{|l|}{ Iron saturated human } \\
\hline lactoferrin $(1 \mathrm{mg} / \mathrm{ml})$ & 0.03 & $27.4 \pm 3.3$ & $49.9 \pm 1.4$ & $50.6 \pm 0.8$ & $52.2 \pm 1.9$ \\
\hline Chelex resin $(20 \%)$ & 0.03 & $21.6 \pm 1.9$ & $56.6 \pm 1.9$ & $74.8 \pm 1.8$ & $82.8 \pm 15.7$ \\
\hline
\end{tabular}

0,2 , and $24 \mathrm{~h}$ results are mean \pm SEM, three experiments; 18 and $96 \mathrm{~h}$ results are from two experiments. 



Figure 9. Evaluation of the role of direct cell contact in the ability of lactoferrin or the synthetic chelator Chelex to enhance lysozyme activity against $E$. coli 5448 in dialysis chamber $(6,000 \mathrm{D}$ exclusion membrane) (mean \pm SEM, three experiments). $(A)$ (Open circles) Bacterial cells and bacto-peptone media alone; (open squares) cells and lactoferrin $(1 \mathrm{mg} / \mathrm{ml})$ in contact, lysozyme $(0.125 \mathrm{mg} /$ $\mathrm{ml}$ ) on opposite side of membrane; (open diamonds) cells and lysozyme in contact, lactoferrin on opposite side of membrane; (closed circles) cells, lysozyme, and lactoferrin in contact. (B) (Open circles) Cells and media alone; (open squares) cells and lysozyme $(0.125 \mathrm{mg} / \mathrm{ml})$ in contact; (open triangles) bacterial cells and Chelex $(0.00692$ $\mathrm{mEq} / \mathrm{ml}$ ) in contact, lysozyme on opposite side of membrane; (solid squares) cells and lysozyme in contact, Chelex on opposite side of membrane; (solid triangles) cells, lysozyme, and Chelex in contact.

thereby provides a permeability barrier that limits penetration of both hydrophobic and hydrophilic molecules. In compensation for this barrier, protein porins allow for diffusion of small molecules into the bacterial cell through transmembrane pores, and inducible specific transport systems provide the transport of sugars, vitamin $B_{12}$, and iron across the membrane (43).

Several groups of agents have been found to damage the Gram-negative outer membrane making the structure more permeable to hydrophobic compounds (10). These include metal chelators such as EDTA and EGTA which remove stabilizing cations and cause release of LPS molecules; and polycations such as polymyxin B nonapeptide, polylysine, and a family of cationic defense proteins of neutrophils which appear to bind to the anionic core components of LPS molecules thereby altering their relationship within the membrane (50). In each instance these agents damage the membrane structure and enhance bacterial susceptibility to hydrophobic substances, such as antibiotics and lysozyme, that have limited ability to penetrate the outer membrane. Thus, the collected observations that lactoferrin causes LPS release and enhances bacterial susceptibility to rifampin and lysozyme strongly suggest that lactoferrin has membrane permeabilizing activity.

Three major mechanisms can be proposed to explain how lactoferrin might alter the permeability barrier of the outer membrane. First, through its metal chelating capacity the protein could remove stabilizing cations in a fashion similar to EDTA (18). Evidence supporting this hypothesis comes from inhibition of the membrane effects by saturation of the protein with iron, and the ability of calcium and magnesium to modulate the activity (20). However, several of the present studies argue strongly against this hypothesis. Specifically, both the inability of lactoferrin to either chelate ${ }^{45}$ calcium or to enhance lysozyme activity in the absence of direct cell contact are inconsistent with divalent cation chelation being the mechanism of action.

A second possibility is that lactoferrin could alter membrane permeability through stimulation of bacterial sidero- phore production. By depleting the environment of available iron, lactoferrin has been found to induce the bacterial production of iron-regulated outer membrane transport proteins (13). The specificity of these transport proteins is still being defined and it is possible that an indiscriminate transport system might allow for the uptake of other molecules aside from iron. Such a mechanism has recently been proposed to explain the enhanced activity of a specific class of catechol-cephalosporins in low iron conditions $(51,52)$. In considering the present studies, the inhibition of lactoferrin activity by iron saturation would support this hypothesis. Still, it would be expected that this mechanism would not require direct interaction with the bacterial cell, and the inability of lactoferrin to enhance lysozyme activity across a dialysis membrane argues against it.

Another potential mechanism for the membrane effects of lactoferrin is through a direct interaction with the bacterial outer membrane. Such a possibility is supported by the work of Valenti and co-workers correlating the ability of hen ovotransferrin and bovine lactoferrin to bind to bacterial strains with the bacteriostatic effects of the proteins against the strains (44, 53). The dialysis chamber time-kill studies we performed similarly support a direct interaction, and the ability of lactoferrin to bind LPS suggests a mechanism of action. Recently, the crystallographic structure of human lactoferrin has been solved to a resolution of $2.8 \AA$ (54). This analysis indicates that one surface subunit of lactoferrin contains nine arginine and lysine residues in close proximity. This cationic region on the protein surface could function as the binding site for LPS through an interaction with the anionic core structure of the latter molecule. This would allow lactoferrin to act similarly to the welldefined polycationic membrane-active agents where the physical presence of the bound protein then alters normal membrane physiology $(21,24)$.

Still this hypothesis must also explain how the effects of lactoferrin are altered by changing either the calcium or magnesium concentrations in the assay or the iron saturation of the protein. Lactoferrin is known to form tetramers in the presence 

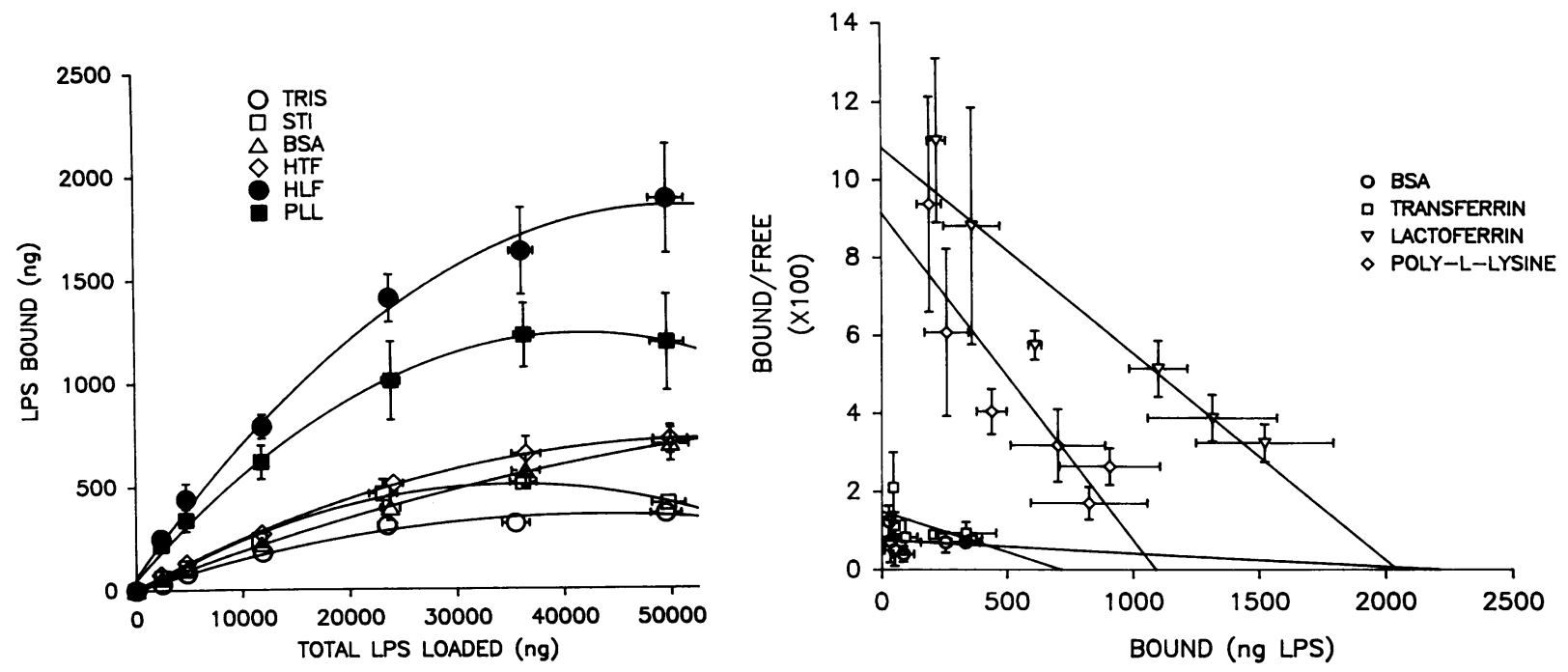

Figure 10. Binding of E. coli $\left[{ }^{3} \mathrm{H}\right]$-LPS to human lactoferrin (HLF), human transferrin (HTF), poly-l-lysine (PLL), soy bean trypsin inhibitor (STI), and bovine serum albumin (BSA) bound to Sepharose, and to Tris-blocked Sepharose (TRIS) (mean \pm SEM, three experiments). $(A)$ The binding curve with second-order linear regression. $(B)$ Corresponding Scatchard plot performed by subtracting nonspecific binding to Trisblocked Sepharose beads; for lactoferrin $r=-0.937$; for poly-l-lysine $r=-0.898$.

of calcium, and this may interfere with its biologic activity (55). Additionally, changes in calcium or magnesium concentration in the environment may alter the amount of the cations incorporated into the outer membrane and thereby influence the membrane susceptibility to membrane-active agents (9). Finally, and most importantly, the divalent cations $\mathrm{Ca}^{2+}$ and $\mathrm{Mg}^{2+}$ have been shown to block the activity of well-characterized polycationic membrane active agents including polymyxin, poly-l-lysine, and aminoglycosides $(22,56,57)$. Studies with BPI have shown that exposure of bacterial cells to either $40 \mathrm{mM} \mathrm{Ca}^{2+}$ or $\mathrm{Mg}^{2+}$ blocks the bactericidal activity of the protein against Gram-negative bacteria, apparently by causing the release of protein from the bacterial cell surface (58-60). Thus, the inhibition of lactoferrin's membrane effects by these two divalent cations is consistent with the protein acting as a polycationic agent. In considering the effects of iron saturation of lactoferrin, both electrophoretic and crystallographic studies indicate that iron binding significantly alters the structural conformation of the protein $(61,62)$. Such a conformational change may then influence an interaction with the bacterial membrane. Clearly each of these hypotheses requires further evaluation.

In these studies lactoferrin was consistently found to be bacteriostatic and not bactericidal. This contrasts with the studies by Arnold and co-workers that describe a direct bactericidal effect of the protein when tested in distilled water $(63,64)$. However, the observed lactoferrin-lysozyme bactericidal effect appears similar to the results of these investigators. It is conceivable that in the studies of these other investigators, the bactericidal effect ascribed to lactoferrin may have been related in part to inadvertent contamination of the lactoferrin preparations with lysozyme.

The lactoferrin-lysozyme effect must be considered in the context of the natural environment. The in vivo concentrations of lactoferrin and lysozyme are highly heterogeneous. Recent work on the concentration of lactoferrin in mucosal fluids has noted levels ranging from $12 \mu \mathrm{g} / \mathrm{ml}$ in mixed respiratory secretions to $6.7 \mathrm{mg} / \mathrm{ml}$ in preterm colostrum $(65,66)$. Lyso- zyme varied from $0.77 \mu \mathrm{g} / \mathrm{ml}$ to $0.06 \mathrm{mg} / \mathrm{ml}$ in these same fluids. Beyond this variability, the packaging and release of the proteins within granules suggests that there is probably significant microheterogeneity of protein concentrations within the individual secretions. Additionally, precise quantitation of two proteins within the phagolysosome of polymorphonuclear leukocytes has not yet been accomplished. Beyond these considerations on protein concentration, there are also high concentrations of calcium and magnesium in most biological fluids that could limit lactoferrin's membrane activity. However, the in vivo distribution of the cations is also not homogeneous; the calcium concentration in the human macrophage phagolysosome has been found to be $<100 \mu \mathrm{M}$ (67). This is then one microenvironment where lactoferrin could enhance the activity of lysozyme. Similarly, the osmolarity of most body fluids is higher than that where the combination of lactoferrin and lysozyme has direct bactericidal activity (68). Yet concurrent damage to both the outer membrane and the murein sacculus produced by the two proteins should continue to occur, and should enhance bacterial susceptibility to other host defense systems such as immunoglobulins, the complement cascade, and phagocytic cells. Thus, as lactoferrin and lysozyme have a similar distribution within mucosal secretions and are primary constituents of the specific granules of polymorphonuclear leukocytes (1-4), it is likely that the observed synergistic interaction is relevant to their host defense properties.

\section{Acknowledgments}

The authors wish to thank Drs. Allen Alfrey and Arnold Schultz for measuring metal concentrations, Dr. Philip Aisen for advice on evaluating calcium binding by lactoferrin, and Mr. Vincent Buric for assistance with the transmission electron microscopy studies.

This work was supported by the Department of Veterans Affairs Research Service. Dr. Ellison is the recipient of a Department of Veterans Affairs Research Associate Career Development award.

\section{References}

1. Masson, P. L., J. F. Heremans, and C. H. Dive. 1966. An iron-binding protein common to many external secretions. Clin. Chim. Acta. 14:735-739. 
2. Bullen, J. J., H. J. Rogers, and E. Griffiths. 1978. Role of iron in bacterial infection. Curr. Top. Microbiol. Immunol. 80:1-35.

3. Cohen, M. S., B. E. Britigan, M. French, and K. Bean. 1987. Preliminary observations on lactoferrin secretion in human vaginal mucus: variation during the menstrual cycle, evidence of hormonal regulation, and implications for infection with Neisseria gonorrhoeae. Am. J. Obstet. Gynecol. 157:1122-1125.

4. Wright, D. G., and J. I. Gallin. 1979. Secretory responses of human neutrophils: exocytosis of specific (secondary) granules by human neutrophils during adherence in vitro and during exudation in vivo. J. Immunol. 123:285-294.

5. Bullen, J. J. 1981. The significance of iron in infection. Rev. Infect. Dis. 3:1127-1138.

6. Iacono, V. J., B. J. MacKay, S. DiRienzo, and J. J. Pollock. 1980. Selective antibacterial properties of lysozyme for oral microorganisms. Infect. Immun. 29:623-632.

7. Selsted, M. E., and R. J. Martinez. 1978. Lysozyme: primary bactericidin in human plasma serum active against Bacillus subtilis. Infect. Immun. 20:728-791.

8. Jolles, P., and J. Jolles. 1984. What's new in lysozyme research? Always a model system, today as yesterday. Mol. Cell. Biochem. 63:165-189.

9. Leive, L. 1974. The barrier function of the Gram-negative envelope. Ann. NY Acad. Sci. 235:109-127.

10. Nikaido, H., and M. Vaara. 1985. Molecular basis of bacterial outer membrane permeability. Microbiol. Rev. 49:1-32.

11. Martinez, R. J., and S. F. Carroll. 1980. Sequential metabolic expressions of the lethal process in human serum-treated Escherichia coli: role of lysozyme. Infect. Immun. 28:735-745.

12. Masson, P. L., J. F. Heremans, J. J. Prignot, and G. Wauters. 1966. Immunohistochemical localization and bacteriostatic properties of an iron-binding protein from bronchial mucus. Thorax. 21:538-544.

13. Finkelstein, R. A., C. V. Sciortino, and M. A. McIntosh. 1983. The role of iron in microbe-host interactions. Rev. Infect. Dis. 5:S759-S777.

14. Spik, G., A. Cheron, J. Montreuil, and J. M. Dolby. 1978. Bacteriostasis of a milk-sensitive strain of Escherichia coli by immunoglobulins and iron-binding proteins in association. Immunology. 35:663-671.

15. Stephens, S., J. M. Dolby, J. Montreuil, and G. Spik. 1980. Differences in inhibition of the growth of commensal and enteropathogenic strains of Escherichia coli by lactotransferrin and secretory immunoglobulin A isolated from human milk. Immunology. 41:597-603.

16. Boesman-Finkelstein, M., and R. A. Finkelstein. 1985. Antimicrobial effects of human milk: inhibitory activity on enteric pathogens. FEMS (Fed. Eur. Microbiol. Soc.) Microbiol. Lett. 27:167-174.

17. Arnold, R. R., M. F. Cole, and J. R. McGhee. 1977. A bactericidal effect for human lactoferrin. Science (Wash. DC). 197:263-265.

18. Ellison, R. T., III, T. J. Giehl, and F. M. LaForce. 1988. Damage of the outer membrane of enteric Gram-negative bacteria by lactoferrin and transferrin. Infect. Immun. 56:2774-2781.

19. Ellison, R. T., III, Q. Luo, and L. B. Reller. 1990. Iron-binding proteins enhance the activity of cefotaxime against Escherichia coli. J. Antimicrob. Che mother. 25:479-481.

20. Ellison, R. T., III, F. M. LaForce, T. J. Giehl, D. S. Boose, and B. E. Dunn. 1990. Lactoferrin and transferrin damage of the Gram-negative outer membrane is modulated by $\mathrm{Ca}^{2+}$ and $\mathrm{Mg}^{2+}$. J. Gen. Microbiol. 136:1437-1446.

21. Vaara, M., and T. Vaara. 1983. Polycations as outer membrane-disorganizing agents. Antimicrob. Agents Chemother. 24:114-122.

22. Hancock, R. E. W., and P. G. W. Wong. 1984. Compounds which increase the permeability of the Pseudomonas aeruginosa outer membrane. Antimicrob. Agents Chemother. 26:48-52.

23. Lehrer, R. I. A. Barton, K. Daher, S. S. L. Harwig, T. Ganz, and M. E. Selsted. 1989. Interaction of human defensins with Escherichia coli. Mechanisms of bactericidal activity. J. Clin. Invest. 84:553-561.

24. Weiss, J., K. Muello, M. Victor, and P. Elsbach. 1984. The role of lipopolysaccharides in the action of the bactericidal/permeability increasing neutrophil protein on the bacterial envelope. J. Immunol. 132:3109-3115.

25. West, S. E. H., and P. F. Sparling. 1985. Response of Neisseria gonorrhoeae to iron limitation: alterations in expression of membrane proteins with out apparent siderophore production. Infect. Immun. 47:388-394.

26. Osserman, E. F., and D. P. Lawlor. 1966. Serum and urinary lysozyme (muramidase) in monocytic and monomyelocytic leukemia. J. Exp. Med 124:921-952.

27. Smith, P. K., R. I. Krohn, G. T. Hermanson, A. K. Mallia, F. H. Gartner, M. D. Provenzano, E. K. Fujimoto, N. M. Goeke, B. J. Olson, and D. C. Klenk 1985. Measurement of protein using bicinchoninic acid. Anal. Biochem. 150:7685.

28. Mokrasch, L. C., and R. W. McGilvery. 1956. Purification and properties of fructose-16-di-phosphatase. J. Biol. Chem. 221:909-927.

29. MacFaddin, J. F. 1980. Biochemical tests for identification of medical bacteria. Williams \& Wilkins Co., Baltimore, MD.

30. Blaser, M. J., J. A. Hopkins, R. M. Berka, M. L. Vasil, and W.-L. L. Wang. 1983. Identification and characterization of Campylobacter jejuni outer membrane proteins. Infect. Immun. 42:276-284.
31. Laemmeli, U. K. 1970. Cleavage of structural proteins during the assembly of the head of bacteriophage T4. Nature (Lond.). 227:680-685.

32. Oakley, B. R., D. R. Kirsch, and N. R. Morris. 1980. A simplified ultrasensitive silver stain for detecting proteins in polyacrylamide gels. Anal. Biochem. 105:361-363.

33. Perez-Perez, G. I., and M. J. Blaser. 1985. Lipopolysaccharide characteristics of pathogenic campylobacters. Infect. Immun. 47:353-359.

34. Hitchcock, P. J. 1983. Aberrant migration of lipopolysaccharide in sodium dodecyl sulfate/polyacrylamide gel electrophoresis. Eur. J. Biochem. 133:685-688.

35. Goldman, R. C., and L. Leive. 1980. Heterogeneity of antigenic-sidechain length in lipopolysaccharide from Escherichia coli $\mathrm{O} 111$ and Salmonella typhimurium LT2. Eur. J. Biochem. 107:145-153.

36. Hukari, R. I., M. Helander, and M. Vaara. 1986. Chain length heterogeneity of lipopolysaccharide released from Salmonella typhimurium by ethylenediaminetetraacetic acid or polycations. Eur. J. Biochem. 154:673-676.

37. Wilkinson, R. G., P. Gemski, Jr., and B. A. D. Stocker. 1972. Non-smooth mutants of Salmonella typhimurium: differentiation by phage sensitivity and genetic mapping. J. Gen. Microbiol. 70:527-554.

38. Joiner, K. A., R. Goldman, M. Schmetz, M. Berger, C. H. Hammer, M. M. Frank, and L. Leive. 1984. A quantitative analysis of C3 binding to O-antigen capsule lipopolysaccharide and outer membrane protein of $E$. coli O111B4.J. Immunol. 132:369-375.

39. Vaara, M., and T. Vaara. 1983. Polycations sensitize enteric bacteria to antibiotics. Antimicrob. Agents Chemother. 24:107-113.

40. Sanderson, K. E., H. Ross, L. Ziegler, and P. H. Makela. 1972. F ${ }^{+}$, HFR, and F' strains of Salmonella typhimurium and Salmonella abony. Bacteriol. Rev. 36:608-637.

41. Miller, J. H. 1972. Experiments in Molecular Genetics. Cold Spring Harbor Laboratory, Cold Spring Harbor, NY.

42. Westphal, O., and K. Jann. 1965. Bacterial lipopolysaccharides. Methods Carbohydr. Chem. 5:83-91.

43. Nikaido, H., and M. Vaara. 1987. Outer membrane. In Escherichia coli and Salmonella typhimurium. Cellular and Molecular Biology. F. C. Neidhardt, J. L. Ingraham, K. B. Low, B. Magasanik, M. Schaechter, and H. E. Umbarger, editors. American Society for Microbiology, Washington, DC. 7-22.

44. Dalmastri, C., P. Valenti, P. Visca, P. Vittorioso, and N. Orsi. 1988. Enhanced antimicrobial activity of lactoferrin by binding to the bacterial surface. Microbiologica (Pavia). 11:225-230.

45. Schryvers, A. B. 1989. Identification of the transferrin- and lactoferrinbinding proteins in Hemophilus influenzae. J. Med. Microbiol. 29:121-130.

46. Lee, B. C., and L. E. Bryan. 1989. Identification and comparative analysis of the lactoferrin and transferrin receptors among clinical isolates of gonococci. $J$. Med. Microbiol. 28:199-204.

47. Wollenweber, H.-W., and D. C. Morrison. 1985. Synthesis and biochemical characterization of a photoactivatable, iodinatable, cleavable bacterial lipopolysaccharide derivative. J. Biol. Chem. 260:15068-15074.

48. Brade, L., K. Brandenburg, H.-M. Kuhn, S. Kusumoto, I. Macher, E. T. Rietschel, and H. Brade. 1987. The immunogenicity and antigenicity of lipid A are influenced by its physicochemical state and environment. Infect. Immun. 55:2636-2644.

49. Labischinski, H., G. Barnickel, H. Bradaczek, D. Naumann, E. T. Rietschel, and P. Giesbrecht. 1985. High state of order of isolated bacterial lipopolysaccharide and its possible contribution to the permeation barrier property of the outer membrane. J. Bacteriol. 162:9-20.

50. Lehrer, R. I., and T. Ganz. 1990. Antimicrobial polypeptides of human neutrophils. Blood. 76:2169-2181.

51. Curtis, N. A. C., R. L. Eisenstadt, S. J. East, R. J. Cornford, L. A. Walker, and A. J. White. 1988. Iron-regulated outer membrane proteins of Escherichia coli K-12 and mechanism of action of catechol-substituted cephalosporins. Antimicrob. Agents Chemother. 32:1879-1886.

52. Watanabe, N.-A., T. Nagasu, K. Katsu, and K. Kitoh. 1987. E-0702, a new cephalosporin, is incorporated into Escherichia coli cells via the tonB-dependent iron transport system. Antimicrob. Agents Chemother. 31:497-504.

53. Valenti, P., P. Visca, G. Antonini, N. Orsi, and E. Antonini. 1987. The effect of saturation with $\mathrm{Zn}^{2+}$ and other metal ions on the antibacterial activity of ovotransferrin. Med. Microbiol. Immunol. 176:123-130.

54. Anderson, B. F., H. M. Baker, G. E. Norris, D. W. Rice, and E. N. Baker. 1989. Structure of human lactoferrin: crystallographic structure analysis and refinement at 2.8 angstrom resolution. J. Mol. Biol. 209:711-734.

55. Bennett, R. M., G. C. Bagby, and J. Davis. 1981. Calcium-dependent polymerization of lactoferrin. Biochem. Biophys. Res. Commun. 101:88-95.

56. Newton, B. A. 1954. Site of action of polymyxin on Pseudomonas aeruginosa: antagonism by cations. J. Gen. Microbiol. 10:491-499.

57. Zimelis, V. M., and G. G. Jackson. 1973. Activity of aminoglycoside antibiotics against Pseudomonas aeruginosa: specificity and site of calcium and magnesium antagonism. J. Infect. Dis. 127:663-669.

58. Mannion, B. A., J. Weiss, and P. Elsbach. 1990. Separation of sublethal 
and lethal effects of the bactericidal/permeability increasing protein on Escherichia coli. J. Clin. Invest. 85:853-860.

59. Weiss, J., M. Victor, and P. Elsbach. 1983. Role of charge and hydrophobic interactions in the action of the bactericidal/permeability-increasing protein of neutrophils on Gram-negative bacteria. J. Clin. Invest. 71:540-549.

60. Weiss, J., R. C. Franson, K. Schmeidler, and P. Elsbach. 1976. Reversible envelope effects during and after killing of Escherichia coli $\mathrm{W}$ by a highly-purified rabbit polymorphonuclear leukocyte fraction. Biochim. Biophys. Acta. 436:154169.

61. Bezwoda, W. R., and N. Mansoor. 1989. Lactoferrin from human breast milk and from neutrophil granulocytes. Comparative studies of isolation, quantitation, characterization and iron binding properties. Biomed. Chromatogr. 3:121-126.

62. Anderson, B. F., H. M. Baker, G. E. Norris, S. V. Rumball, and E. N. Baker. 1990. Apolactoferrin structure demonstrates ligand-induced conformational change in transferrins. Nature (Lond.). 344:784-787.

63. Arnold, R. R., M. Brewer, and J. J. Gauthier. 1980. Bactericidal activity of human lactoferrin: sensitivity of a variety of microorganisms. Infect. Immun. 28:893-898.

64. Bortner, C. A., R. D. Miller, and R. R. Arnold. 1986. Bactericidal effect of lactoferrin on Legionella pneumophila. Infect. Immun. 51:373-377.

65. Mathur, N. B., A. M. Dwarkadas, V. K. Sharma, K. Saha, and N. Jain 1990. Anti-infective factors in preterm human colostrum. Acta Paediatr. Scand. 79:1039-1044.

66. Thompson, A. B., T. Bohling, F. Payvandi, and S. I. Rennard. 1990. Lower respiratory tract lactoferrin and lysozyme arise primarily in the airways and are elevated in association with chronic bronchitis. J. Lab. Clin. Med. 115:148-158.

67. Pollack, C., S. C. Straley, and M. S. Klempner. 1986. Probing the phagolysosomal environment of human macrophages with a $\mathrm{Ca}^{2+}$-responsive operon fusion in Yersinia pestis. Nature (Lond.). 322:834-836.

68. Lentner, C. 1981. Geigy Scientific Tables. Volume 1. Units of Measurement, Body Fluids, Composition of the Body, Nutrition. Ciba-Geigy Corp., West Caldwell, NJ. 